\title{
The Mechanism of Imported Iron Ore Price in China
}

\author{
Zhijie Fu \\ University of Alberta, Edmonton, Canada \\ Email: steakdream@outlook.com
}

How to cite this paper: Fu, Z.J. (2018) The Mechanism of Imported Iron Ore Price in China. Modern Economy, 9, 1908-1931. https://doi.org/10.4236/me.2018.911120

Received: October 25, 2018

Accepted: November 19, 2018

Published: November 22, 2018

Copyright $\odot 2018$ by author and Scientific Research Publishing Inc. This work is licensed under the Creative Commons Attribution International License (CC BY 4.0).

http://creativecommons.org/licenses/by/4.0/

\begin{abstract}
This study analyzes the relationship and the issues between iron ore market from demand and supply side. It empirically explains how and why the import iron ore price in China fluctuates through Baltic Dry Index, Dollar Index, iron ore production, volume of import iron ore, and also compares the forecast ability between Vector Error Corrected Model (VECM) and ARIMA model. This paper concludes the following finds. Firstly, there is no structural break and seasonality. The data are first degree stationary and have 1 cointegration relationship between variables. In addition, the impulse response function shows that the import iron ore price is positively sensitive to BDI and negatively sensitive to Dollar Index, and it reveals the fact that China has less power to influence the iron ore price even if it has been the largest buyer. Finally, forecast ability assessment shows that VECM outperforms ARIMA model.
\end{abstract}

\section{Keywords}

Iron Ore Price, ARIMA, Cointegration, IRF, VECM

\section{Introduction}

Steel plays a significant role in modern economy. As a complicated process, steel industry is not only influenced by upstream industries such as iron ore mining, coal mining, logistics, trading, steel facility, etc., but also by downstream industries, for instance, construction, infrastructure, machinery manufacturing, transportation, automotive, railway construction, military, marine engineering industry etc., as well as political and economic policies in different countries.

Since these downstream industries are the leading industries in industrialization, steel production has been the indicator of economic development. Even though the role of steel is becoming weaker in recent years, the proportion of gross value of industrial output of steel industry to Gross Domestic Product 
(GDP) was still more than 13 percent $^{1}$ in 2012 in China. From the country's perspective, China has rapidly increased its import iron ore from about 30 percent to 60 percent in world total import iron ore in 2005-2014² it has become to be the largest importer of iron ore in the last decade. From firms' perspective, the cost of iron ore is usually a considerable component in the cost of steel production. For example, Wuhan Iron and Steel Company Limited (WISCO, Ltd) purchased about 9 million ton domestic iron ore and 20 million ton import iron ore, which costs 3.2 billion CNY and 8.2 billion CNY in 2015 respectively. Basically, the cost of iron ore is about half of WISCO's cost of unit production ${ }^{3}$, and two third of the iron ore used in 2015 is import iron ore.

Therefore, the price of import iron ore can significantly affect the cost and selling price of steel products, and further influence other downstream industries through the long chain effect. This paper attempts to make an effort in the study of why the import iron ore price fluctuates and how it will fluctuate in the future, and hopes it can help the policy-makers of steel companies to avoid unnecessary losses due to the fluctuation of import iron ore price and the decision-makers of China to formulate macro policies to stabilize the price through indirected chain.

In this paper, Section 2 reviews previous literature. Section 3 discusses the theory part for the commodity price. Section 4 discusses the supply and demand market of iron ore and tries to analyze import iron ore price based on historical data in China. Section 5 talks about the formulation of the data. Section 6 discusses ARIMA model including the problem of seasonal adjustment, structural breaks, unit root and lag length selection. Section 7 discusses VECM including lag length selection, cointegration and Granger causality. It also tries to analyze why and how the import iron ore price will fluctuate through variance decomposition and IRF. Section 8 does the forecast evaluation of two models and one year ahead forecast. Section 9 concludes. Moreover, this paper mainly contributes a wide review about the demand and supply market of import iron ore and provides a comprehensive comparison between ARIMA model and VECM through the assessment of the ability of fitting and forecasting. Also, it analyses different factors which are significant to the fluctuation of import iron ore price in China through different ways such as Granger Causality and impulse response function, and it gives suggestions that how Chinese government and steel industry to minimize the potential losses from import iron ore price fluctuation.

\section{Literature Review}

There is a long history of the study of commodity, and the literature about commodity is quite extensive. Basically, there are two approaches to studying a commodity, "theory-based" study and empirical study.

For the approach of "theory-based" study, a typical study is to estimate demand

${ }^{1}$ Source: National Bureau of Statistics of the People's Republic of China.

${ }^{2}$ Source: Worldsteel: Steel Statistical Yearbook 2015.

${ }^{3}$ Source: WISCO Ltd annual report 2015. 
and supply function. For example, Zhu [1] estimates the demand and supply equations by using instrumental variables for sample year 1960 to 2010 . He considers the demand equation as regressing iron ore quantity at time $t$ on iron ore price at time $t$ and $t-1$, scrap price at time $t$, demand shock and world GDP at time $t$. The supply equation contains iron ore quantity at time $t$ and price at time $t$ and $t-1$, interest rate at time $t$, time and supply shock at time $t$. And he thinks world GDP, interest rate and scrap price are not significantly correlated with iron ore price at time $t$, and thus they are valid instruments. By using 3SLS method, he finds that except interest rate, other variables are statistically significant at $1 \%$, and he concludes long-run demand curve is downward sloping and long-run supply curve is upward sloping and it agrees with perfect competition market. However, the author also concludes that the perfect competition market assumption is incorrect since the iron ore market exhibits a bilateral negotiation oligopoly from market structure analysis. Also, according to Jones [2], iron ore is not homogeneous, and the trade of iron ore is largely between iron ore cartel and large buyers. This paper was written early, but the situation of large buyers and sellers, which should be considered as oligopoly instead of perfect competition market, still exists; the sellers group does not change much, and the major buyer shifts from Japan, Korea and Chinese Taipei to China currently.

Another example of "theory-based" study is to estimate the cost function of this commodity. For instance, Crompton et al. [3] establish a generalized Leontief cost function based on the data from 69 integrated plants. This paper considers total production cost as a function of production of iron ore and input prices including the prices of run of mine (ROM) ore, coke, energy, electricity, capital and labour. The paper concludes that there is a significant economy of scale in iron ore industry, and there is a presence of large fixed costs and quasi-fixed labour costs. Also, Pustov et al. [4] consider two approaches to forecasting long-term iron ore price: marginal cost and incentive price. They find that long-term iron ore price is significant to the project of greenfield iron ore. The main disadvantage of this kind of study is that it is usually unable to do the forecast because there is no dynamic interaction among periods.

In empirical study approach, basically, there are two aspects to study the commodity price and to forecast it. The first aspect is to consider univariate model. This kind of models sometime are hard to beat in comparing the goodness of fit or forecast ability with other models, though they do not have economic meaning behind; this kind of model usually relies on the autocorrelation feature of the data and the relationship of the objective variable and other economic indicators cannot be analyzed. The simple approach is to estimate an Autoregressive Integrated Moving Average (ARIMA) model. For example, Cummins and Griepentrog [5] forecast auto-mobile insurance paid claim costs. After removing the trend and seasonal-adjustment, they use time-varying ARIMA model to see if there is a tendency for the cost to grow up. A more recent univariate model can be Artificial Neural Network (ANN) model. ANN type models are widely used in financial, medical, engineering, etc. sectors. 
Zhang [6] analyzes the ability to forecast Wolf s sunspot, Canadian lynx and British pound/US dollar exchange rate by considering ARIMA, ANN and hybrid model. Besides, Eswaran et al. [7] forecast infant mortality rate by using ARIMA, ANN and linear regression models. They compare Mean Absolute Error (MAE), Mean Absolute Percentage Error (MAPE) and Root Mean Square Error (RMSE) to evaluate the forecasting ability of ARIMA, ANN and linear regression, and they find that ANN works significantly better than the other two models, while linear regression model does the worst. However, Khalifa et al. [8] compare the ability of forecasting of gold returns with ANN and Generalized Autoregressive Conditional Heteroskdasticity (GARCH) model. They conclude GARCH has slightly better prediction than ANN by comparing Mean Square Error (MSE). The evidence of which model is better is not quite clear, however, in general, both of ARIMA and ANN models can be the control groups to assess the goodness of other multivariate models.

For the multivariate models, a natural starting point is Ordinary Least Squares (OLS). Tcha and Wright [9] estimate the demand of China's import for Australian iron ore for a sample period 1973-1996 by regressing China's imports of Australia's iron ore on China's steel production, real GDP per capita of China, relative price of Australian iron ore comparing to the world, a measure of Australian labor disputes and a measure of Chinese government policy. They find that steel production is the most significant determinant of iron ore import of China, also relative price of iron ore, labour disputes in Australia and Chinese government policy are statistically significant. Also, ANN models can be implemented to forecast iron ore price. Moghaddam et al. [10] introduce a multivariate ANN type model to forecast global monthly iron ore price by trying different layers. They train the data which include price of iron ore, steel production index, oil price, index of iron ore production, Aluminium price and internal gross GDP index, and they achieve a relatively low RMSE, which is 0.1885 . They conclude that steel production index, internal GDP have the highest impact on the price. Besides, Grey model is developed by Julong [11] which is mainly used by Chinese scholars to do forecast. For example, Ma et al. [12] implement Grey model to forecast the volume of import iron ore and the consumption of iron ore in China by using a relatively small sample which is annual data from 1995 to 2010 .

Haque et al. [13] consider a Vector Error Correction Model (VECM) between the exchange rate AUD/USD and iron ore price, and they find out that AUD/USD has no Granger-causality to iron ore price and iron ore price has Granger-causality to AUD/USD, however, they find that in the Impulse Response Function (IRF) graph, AUD/USD has impact on the price of iron ore. Wårell [14] also uses VECM approach to analyze the iron ore market. This paper uses monthly iron ore price from January 2003 to August 2012 and includes GDP growth in China and freight rates, and it shows that they are cointegrated. This paper aims at the analysis of the impacts of other variables to the price, and it shows that GDP growth in China has the largest impact. 


\section{Theory}

A basic theory for a commodity price is the law of demand and supply; it is basically a representation of demand and supply function. For instance, keeping other variables constant, higher price results that lower quantity is demanded and higher quantity is supplied. It reveals that the price should be correlated with the quantity of demand and supply.

To see how iron ore price is determined, $\mathrm{He}$ and $\mathrm{Yu}$ [15] build a theoretical model for international iron ore market by considering a bilateral bargaining negotiate model:

$$
\begin{aligned}
& \pi_{s}(p, q)=R(q)-p q \\
& \pi_{s}(p, q)=p q-C(q)
\end{aligned}
$$

where subscript $S$ is "Seller", $B$ is "Buyer". $\pi$ is the profit. $R(q)$ is the revenue that the buyer gains from selling its products. $C(q)$ is the total cost. Therefore, the Pareto equilibrium $\left(p^{\star}, q^{\star}\right)$ of this game should satisfy:

$$
\begin{gathered}
\pi\left(p^{\star}, q^{\star}\right)=\pi_{S}\left(p^{\star}, q^{\star}\right)+\pi_{B}\left(p^{\star}, q^{\star}\right) \\
V_{i}^{\star}=\pi-\sigma_{j} V_{j}^{\star}, i=S, B
\end{gathered}
$$

where $V$ is the pay-off of the player. $\sigma$ is the discount factor. After simplification, the following result is obtained by equalizing $p_{S}^{\star}$ and $p_{M}^{\star}$ :

$$
p^{\star}=\frac{r_{S}}{r_{S}+r_{M}} \frac{R(q)}{q}+\frac{r_{B}}{r_{S}+r_{B}} \frac{C(q)}{q}
$$

where $r$ is the discount factor. $p^{\star}$ is actually the market clearing price, and this equation is saying that the price is determined by the quantity of demand and supply, revenue from selling the final products of iron ore and the total cost of producing iron ore.

\section{Supply and Demand Market}

The reserve of iron ore in the world is abundant. From the perspective of country level, according to U.S. Geological Survey (USGS), the world crude ore reserves in 2015 was around 183.8 billion metric tons. As shown in Table 1, the top five countries Australia, Russia, Brazil, China and United States have more than 70 percent gross weight reserves in the world.

The country, China, analyzed in this paper was ranked No. 4 in world iron ore reserve in 2015, however, it does not mean that the iron content is also rich. The iron ore is a compound containing several different elements. A common method to classify how much Fe the iron ore has is called the grade of ore. The major classifications have magnetite $\left(\mathrm{Fe}_{3} \mathrm{O}_{4}\right)$, hematite $\left(\mathrm{Fe}_{2} \mathrm{O}_{3}\right)$, limonite $\left(\mathrm{FeO}(\mathrm{OH}) \cdot \mathrm{nH}_{2} \mathrm{O}\right)$ and siderite $\left(\mathrm{FeCO}_{3}\right)$, and their iron contents theoretically can be up to about $72 \%, 70 \%, 60 \%$ and $48 \%$ respectively. Thus, it is hard to get an accurate measurement of overall grade due to the lack of data. To get the sense of the grade of iron ore reserve in each country, the column "percentage" is obtained by dividing iron content by crude ore in Table 1 . Since element Fe is what 
steel companies want, the percentage of iron content in crude ore can represent how much steel these steel companies can produce. It is evident that even the reserves of iron ore in China is one of the largest country in the world, the actual iron content in the reserves is low; it is ranked to be penultimate. Therefore, China has relatively large iron ore reserve in the world but the grade of its iron ore is very low.

It causes some problem about Chinese mining industry. According to Mysteel Database, the cost of mining industry in China is about $480 \mathrm{CNY} /$ metric ton, which is converted to 70 U.S Dollar at $6 \mathrm{CNY} / \mathrm{USD}^{4}$. However, the average cost per unit of BHP is 15.21 U.S. Dollar in 2015, which is only about one fifth of Chinese mining industry. The high cost of Chinese mining industry can heavily reduce the competitive power of domestic iron ore comparing to import iron ore.

A country having more iron ore reserves does not mean that it produces more iron ore; sustainable development, mining cost and so on can affect how much the country produces. Table 2 shows the iron ore production of top 8 countries with the most reserves. There are 4 countries which produce more than $10 \%$ of world iron ore, Australia, Brazil, China and India. In the past 5 years, Australia persistently produced the most iron ore in the world, and China and India decreased their production. In 2014, the total production of Australia and Brazil even exceeded $50 \%$ of world production. Thus, the data shows that few countries produce most of iron ore.

From the perspective of firms, most of the iron ore is produced by few firms. There are several major producers in the world: Rio Tinto, BHP Billiton, Vale SA, Metalloinvest and Fortescue Metals Group (FMG). Figure 1 shows iron ore production of these five firms in 2015 from Mysteel Database; the data is generated by the summation of 4 quarters production of each firm. In 2015, the total production of iron ore by these five firms was 1134.55 million metric tons; Vale produced the most, which was close to $30 \%$ of total five firms. Also, according to the data in Worldsteel Yearbook 2015, the world imports of iron ore in 2014 was 1435.34 million metric tons. It means that the ratio of the production of five firms and world imports is almost $80 \%$. Therefore, it shows that from the firm's perspective, few mining companies produce the most iron ore.

On the supply side, world iron ore production increases in the past five years. Also, the iron ore import is increasing over the past decade on the demand side.

As shown in Figure 2, in the last decade, import iron ore continuously increases. Jones [2] analyzes the iron ore market in the last century, and Japan and South Korea were the major importers of iron ore. However, China is occupying the position of the largest importer; the share of China's import increases from less than half of world import iron ore in 2005 to around two-third in 2014, and the share of Japan and South Korea is sustained decreasing. Therefore, China is becoming the main force of iron ore consumption. This chapter also overthrows the assumption that Zhu [1] makes which assumes the iron ore market is perfect ${ }^{4}$ Integer part of the exchange rate on Dec 31, 2015. Source: Yahoo finance. 
competition market. In conclusion, the situation that Jones [2] indicates where large buyer and large sellers play in the market still exists; the major buyer is China, and the major sellers are four companies Rio Tinto, BHP Billiton, Vale SA and FMG.

Table 1. Iron Ore Reserves in $2015^{\mathrm{a}}$ (Weight: millions of metric tons; Percentage: \%).

\begin{tabular}{ccccc}
\hline No. & Country & Crude ore & Iron content & Percentage $^{\mathrm{b}}$ \\
\hline 1 & Australia & 54,000 & 24,000 & 44 \\
2 & Russia & 25,000 & 14,000 & 56 \\
3 & Brazil & 23,000 & 12,000 & 52 \\
4 & China & 23,000 & 7200 & 31 \\
5 & United States & 11,500 & 3500 & 30 \\
6 & India & 8100 & 5200 & 64 \\
7 & Ukraine & 6500 & 2300 & 35 \\
8 & Canada & 6300 & 2300 & 37 \\
9 & Sweden & 3500 & 2200 & 63 \\
10 & Iran & 2700 & 1500 & 56 \\
11 & Kazakhstan & 2500 & 900 & 36 \\
12 & South Africa & 1000 & 650 & 65 \\
13 & Other & 18,000 & 9500 & 53 \\
& Total & 185,100 & 85,250 & 46 \\
\hline
\end{tabular}

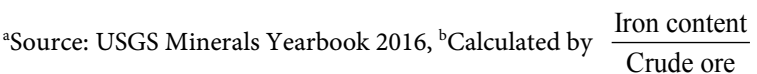

Table 2. Iron Ore Production 2010-2014 (Production: millions of metric tons).

\begin{tabular}{|c|c|c|c|c|c|c|c|c|c|c|}
\hline \multirow{2}{*}{ Country } & \multicolumn{2}{|l|}{2010} & \multicolumn{2}{|l|}{2011} & \multicolumn{2}{|l|}{2012} & \multicolumn{2}{|l|}{2013} & \multicolumn{2}{|l|}{2014} \\
\hline & Production & $\%$ & Production & $\%$ & Production & $\%$ & Production & $\%$ & Production & $\%$ \\
\hline Australia & 432.779 & 23 & 477.332 & 25 & 520.032 & 27 & 608.9 & 31 & 723.7 & 36 \\
\hline Russia & 99.06 & 5 & 103.805 & 5 & 103.337 & 5 & 102.497 & 5 & 101.448 & 5 \\
\hline Brazil & 372 & 20 & 397 & 20 & 380.086 & 20 & 391.1 & 20 & 399.4 & 20 \\
\hline China & 358.5 & 19 & 345.07 & 18 & 336.07 & 17 & 266.087 & 13 & 193.215 & 10 \\
\hline $\begin{array}{l}\text { United } \\
\text { States }\end{array}$ & 49.9 & 3 & 54.7 & 3 & 54 & 3 & 52 & 3 & 54.3 & 3 \\
\hline India & 209 & 11 & 191.8 & 10 & 152.6 & 8 & 136.1 & 7 & 129.8 & 6 \\
\hline Ukraine & 79.17 & 4 & 81.189 & 4 & 80.826 & 4 & 83.696 & 4 & 82.409 & 4 \\
\hline Canada & 37.501 & 2 & 37.101 & 2 & 39.401 & 2 & 41.841 & 2 & 44.196 & 2 \\
\hline World & 1870.062 & 100 & 1943.788 & 100 & 1931.356 & 100 & 1977.242 & 100 & 2001.131 & 100 \\
\hline
\end{tabular}

${ }^{5}$ Source: Worldsteel: Steel Statistical Yearbook 2015. 


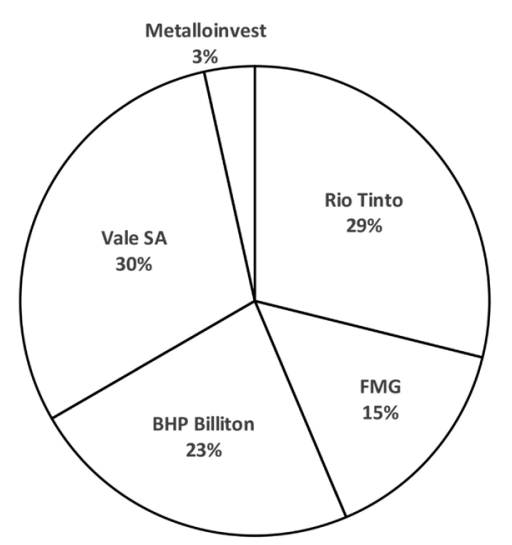

Figure 1. Production of iron ore in 2015, ${ }^{\text {a }}$ Source: Mysteel Database.

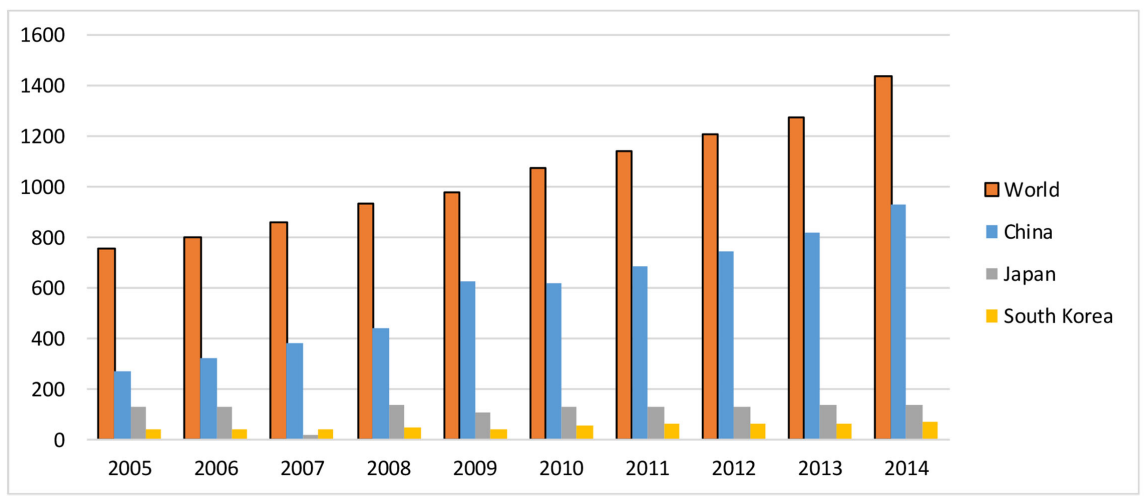

Figure 2. Import Iron Ore 2010-2014 (Weight: millions of metric tons), ${ }^{\text {a }}$ Source: Worldsteel Yearbook 2015.

\section{Variable Selection}

Figure 3 shows the average price of iron ore fines from Vale in 2004-2015 form Mysteel Database. The raw data is transformed from quarterly data to monthly data by using the last observation. From 2004, the price is continuously increasing until 2008 which is the local maximum. The rapid increase of China's import iron ore seems to be the reason why Vale iron fines price increased as shown in Figure 2. In 2008, affected by the world financial crisis, most of the bulk raw materials prices dropped including iron ore price. Also, in Figure 2, the growth of import iron ore in China was more than doubled in 2009 than 2008, as a result, it seems that the increase of growth caused the price of iron ore to be also increased. The reason why China increased its import iron ore but the rest of world did not catch the growth of import iron ore is that China implemented the so called " 4 trillion economic stimulus" package plan. It reached its peak point in 2011 and dropped until now except for a small rebound in 2012-2013. In general, downward trend may be driven by the mass production from FMG as the representative for the new mining companies. FMG was established in 2003, and it started mass production in 2008, which rapidly raised its market share. It caused high speed increase of iron ore production even though countries around 


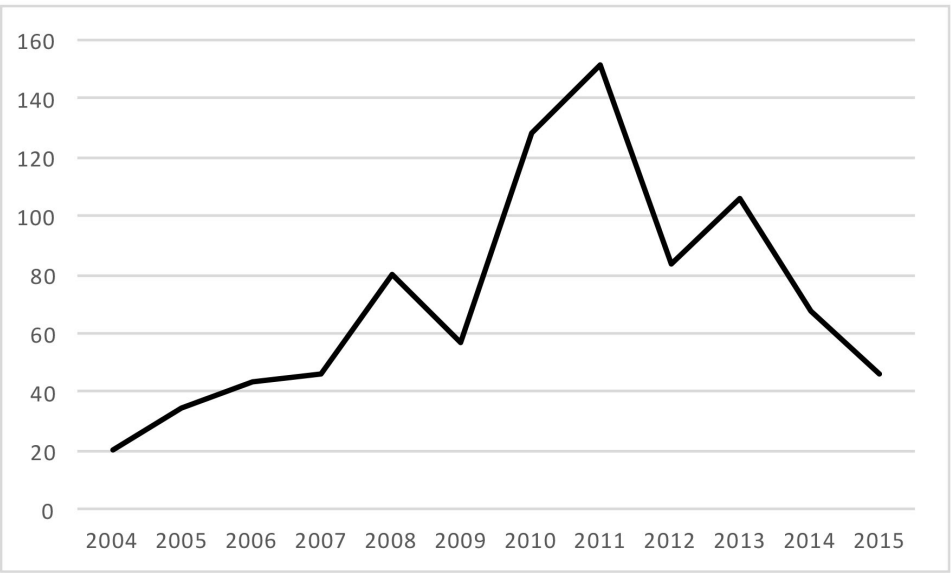

Figure 3. Average price from Vale, Iron Ore Fines 2004-2015 ${ }^{\mathrm{a}}$ (USD per

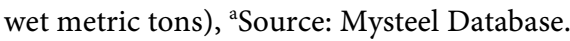

the world were still suffering from the financial crisis after 2008. Besides, oil price sustains low price since late 2014; it also reduces the freight and causes lower price since the import iron ore of China mainly relies on ocean shipping.

In the past decade, the price of import iron ore is not identical. There are basically two types of price: long-term price based on annual negotiation and spot price. Before 2010, the price was mainly determined by the annual long-term contract. In 2010, Vale SA firstly announced to change their marketing policy; annual long-term contract is replaced by quarterly, monthly or daily contract.

Since the annual long-term contract sets the FOB price, but due to ocean freight and other fees, the fluctuation of FOB and CIF prices may be not the same. Besides, some of the import iron ore is traded at spot price (mainly imported from India), and the volume of this part is increasing in China nowadays. Therefore, considering only FOB or spot price may be not appropriate to model "import iron ore price". Also, "iron ore" is a general term, and iron ore is classified by its status in the trading market. For example, there are lump ore, fine ore and pellet, and the grades vary from $50 \%$ to $60 \%$. Therefore, a measurement of iron ore price is needed. In this paper, the monthly volume of import iron ore (metric tons) and total cost of import iron ore (US Dollar) in China are used to obtain the measurement of import iron ore price.

$$
\text { price }_{t}=\frac{\text { Total cost of imported iron ore }}{t}
$$

Also, according to Haque et al. [13], exchange rate may have influence on iron ore price since iron ore is usually settled by US dollar, when the producers and buyers observe the change of exchange rate, they may adjust the price to compensate the change. Therefore, to capture the fluctuation of exchange rate changes, monthly trade weighted US Dollar index: Broad from Fred 2 should be included.

Since CIF price $=$ FOB price + insurance + freight, the fluctuation of freight may have influence on CIF price which is estimated by price $_{t}$. Baltic Dry Index 
(BDI) is calculated from the weighted spot rates of several major courses, and it is a measurement of freight of bulk cargo. Therefore, to capture the fluctuation of freight, BDI should be considered. Since BDI is daily data, to transform into monthly data, the average of each month is used.

In addition, China itself also produces iron ore. If the domestic iron ore production rapidly increased, China may have less incentive to import foreign iron ore. However, the grade of domestic ore is much lower than the world average grade of iron ore. Thus, even if the growth of the volume of domestic production is larger than the growth of foreign iron ore production, the consequence of this kind of shock to the import iron ore price is not clear. Besides, given the fact that most of mines in China are underground mining and the cost of mining is much higher than import iron ore, domestic iron ore may have less competitive power than import iron ore and thus have weak influence on the import iron ore price.

On the supply side, when the iron ore supply increases while demand is constant, the price should be affected. Also, given the fact that price declines from the peak in 2011 and it may be caused by the mass production of FMG, the production of iron ore of the rest of world should have impact on the price. However, there is no monthly production data available for each company or each country. Instead, an aggregated export iron ore of major export countries is used. The countries are Australia and Brazil. Since there are 3 observations of Brazil and Australia missing, the missing observations are filled by log-linear interpolation method.

The source of total cost of import iron ore, domestic and international iron ore production and BDI are Mysteel database. Total volume of import iron ore is from Worldsteel Association Statistical Yearbook, and trade weighted US Dollar index: Broad is from Fred 2. Since after 2016, the largest iron ore buyer, China, had implemented the so called "Macroscopic Control", it may have huge influence on the stability of the data. Therefore, monthly data with sample period 2005 M01 to 2015 M12 is used.

Price, volume of import iron ore, domestic iron ore production and foreign iron ore production are natural log-transformed. Table 3 is the descriptive statistics. It shows that BDI have surprisingly high standard deviation and it has been heavily fluctuated; the maximum is $10,843.65$ and the minimum is 519.1667. It is mainly because of the boost of 2007 and it goes down straightly after the financial crisis in 2009.

\section{ARIMA Model}

In the last century, central banks used hundreds equations to forecast GDP growth, however, the results were not good. After ARIMA model was introduced, it easily outperforms the forecast of those hundreds equations. Therefore, the question that how the import iron ore price will fluctuate can be answered by considering the empirical approach, and ARIMA model is the starting point. Also, since ARIMA model usually provides a solid forecast, it can work as the 
Table 3. Descriptive statistics ${ }^{\mathrm{a}}$.

\begin{tabular}{ccccccc}
\hline & lpri & bdiavg & dollar & limport & loredo & loreint \\
\hline Mean & 4.583756 & 2824.132 & 89.47909 & 17.67935 & 8.978971 & 18.01895 \\
Median & 4.563637 & 1957.818 & 87.928 & 17.78352 & 9.053722 & 18.02024 \\
Maximum & 5.170087 & 10843.65 & 99.215 & 18.38266 & 9.541972 & 18.60707 \\
Minimum & 3.937378 & 519.1667 & 80.471 & 16.71487 & 7.636077 & 17.40734 \\
Std. Dev. & 0.349897 & 2462.975 & 5.375799 & 0.422993 & 0.446143 & 0.313298 \\
Observations & 132 & 132 & 132 & 132 & 132 & 132 \\
\hline
\end{tabular}

${ }^{a}$ lpri: natural log-transformed price; bdiavg: monthly averaged BDI; dollar: monthly trade weighted US Dollar index; limport: natural log-transformed amount of import iron ore; loredo: natural log-transformed amount domestic iron ore production; loreint: natural log-transformed amount foreign iron ore production.

benchmark model to give a foundation assessment of the prediction ability of multivariate model.

\subsection{Seasonal Adjustment}

Seasonal adjustment usually needs to be done in high frequency data. For example, the monthly sale of ice cream is a typical case of seasonal data; the sale in summer is usually higher than in winter. For the case of iron ore price, the seasonal effect should be analyzed by considering the seasonality of demand and supply of iron ore. On the demand side, steel companies are the typical buyer, and the steel production may appear to be seasonal. The major consumer of steel is real estate industry, and the weather conditions such as raining or freezing can affect the capacity utilization rate of real estate industry. Also, Chinese people have about a week national holidays in around February to celebrate the Spring Festival, and the demand of iron ore may be less than other months, thus the price of iron ore can be affected. To do seasonal adjustment, addictive Moving Average model is assumed. The model is

$$
y_{t}=S_{t}+T_{t}+C_{t}+e_{t}
$$

where $y_{t}$ is the observation at time $t, S_{t}$ is the seasonal component at time $t$, $T_{t}$ is the trend component at time $t, C_{t}$ is the cycle component at time $t, e_{t}$ is everything else.

Thus, the seasonally adjusted data is obtained from:

$$
y_{t}-S_{t}=T_{t}+C_{t}+e_{t}
$$

Therefore, the price of iron ore, the volume of domestic and foreign production of iron ore and the volume of import iron ore are seasonally adjusted.

\subsection{Structural Breaks}

Structural breaks can usually occur when the industry structure changes or there are some permanent shocks to the industry. In the previous section, the history of iron ore pricing is discussed. There are several potential breaks. The first one 
is at some point in 2008. When the new players represented by FMG found that the price was continuously increasing before 2008, they entered to the market, and FMG started mass production in 2008. FMG occupied around 15\% market share among five companies in 2015 , and it seems to be the force which raises the total world iron ore production and lowers the iron ore price after 2008. The second potential break is at mid 2009. A sequence of events happened at that time. The spokesman of Ministry of Commerce of China commented that the joint venture of BHP Billiton and Rio Tinto is applicable to anti-trust law in June. In July, four employees of Rio Tinto Shanghai office were arrested for espionage and bribery. If their bribery causes unusual high price, the price may be changed at least for a while after their arrest. The other potential break point is around 2010. At that time, the method of pricing is changed from mainly annual long-term contract to daily, monthly, quarterly pricing. The change of pricing method may cause some change in trend, mean, etc.

Since there are multiple unknown potential structural breaks, the only test for structural breaks taught in Master level, chow test, can not be done. Bai and Perron [16] [17] [18] demonstrate a method Sequential $L+1$ breaks vs. $L$ to test multiple structural breaks. The basic idea of this test is that it tests sequentially whether there is 0 vs. 1 break, if it is rejected, it then tests 1 vs. 2 , etc. Test results are shown in Table 4.

The test failed reject 0 vs. 1 and shows there is no structural break. It seems that the price has no structural break even if the analysis about potential structural breaks above is logical. The possible reason may be because of the way of generating this price. This price is generated by dividing the cost by the volume of import iron ore, and due to the fact that it takes a month to ship the import iron ore to China, and the payment could be delivered in a delayed period, the structural changes for price may be vanished.

\subsection{Unit Root Test}

In time series method, the series is covariance stationary if mean and covariance do not change over time. Stationary is usually a requirement of time series model, otherwise the model will explode. To test it, Augmented Dickey-Fuller (ADF) test is used. Results are shown in Table 5.

All variables have unit root, and they do not have unit root after first differenced.

\subsection{Lag Length Selection}

ARMA model is based on the autocorrelation of the data, however, the length of lags needs to be determined. The general form of this model is :

$$
\begin{aligned}
& D(\text { lpri })_{t}=\phi_{1} D(\text { lpri })_{t-1}+\phi_{2} D(\text { lpri })_{t-2}+\cdots+\epsilon_{t}+\theta_{1} \epsilon_{t-1}+\theta_{2} \epsilon_{t-2} \\
& \epsilon_{t} \sim W N\left(0, \sigma^{2}\right)
\end{aligned}
$$

The comparison of different $p$ and $q$ for ARIMA $(p, q)$ based on AIC and BIC for $D($ lpri $)$ in Table 6. 
The results of AIC and BIC are different, which happens frequently in practice. In this paper, small model ARMA $(1,2)$ is chosen, and the general expression of $\operatorname{ARMA}(1,2)$ is:

$$
\begin{aligned}
& D(\text { lpri })_{t}=\phi D(\text { lpri })_{t-1}+\epsilon_{t}+\theta_{1} \epsilon_{t-1}+\theta_{2} \epsilon_{t-2} \\
& \epsilon_{t} \sim W N\left(0, \sigma^{2}\right)
\end{aligned}
$$

The estimation results are shown in Table 7 and the estimation equation is shown in Equation 10; it suggests that this ARMA model is stationary and it converges.

$$
D(\text { lpri })_{t}=-0.001446-0.039393 D(\text { lpri })_{t-1}+\epsilon_{t}+0.872595 \epsilon_{t-1}+0.323792 \epsilon_{t-2}(10)
$$

To test whether the residual in Equation (10) exhibits serial correlation and well-behaved, Ljung-Box Q-statistics is performed. The test results are shown in Figure 4, and it shows that there is no excess in autocorrelation and partial correlation.

Table 4. Sequential L +1 breaks vs. L.

\begin{tabular}{|c|c|c|c|c|c|c|}
\hline & Type $(c, t, k)$ & ADF statistics & $1 \%$ level & $5 \%$ level & Prob. & Conclusion \\
\hline lpri & $(c,-, 2)$ & -1.120573 & -3.481623 & -2.883930 & 0.7064 & unit root \\
\hline D (lpri) & $(c,-, 1)$ & -6.498407 & -3.480425 & -2.883408 & 0.0000 & no unit root \\
\hline bdiavg & $(c,-, 1)$ & -2.536288 & -3.481217 & -2.883753 & 0.1093 & unit root \\
\hline D (bdiavg) & $(c,-, 0)$ & -7.309591 & -3.481217 & -2.883753 & 0.0000 & no unit root \\
\hline dollar & $(c,-, 1)$ & -1.474510 & -3.481217 & -2.883753 & 0.5435 & unit root \\
\hline $\mathrm{D}$ (dollar) & $(c,-, 0)$ & -7.548273 & -3.481217 & -2.883753 & 0.0000 & no unit root \\
\hline limport & $(c, t, 2)$ & -3.390897 & -4.031309 & -3.445308 & 0.0571 & unit root \\
\hline $\mathrm{D}$ (limport) & $(c, t, 1)$ & -12.65140 & -4.030729 & -3.445030 & 0.0000 & no unit root \\
\hline loredo & $(c, t, 2)$ & -1.434483 & -4.030729 & -3.445030 & 0.8463 & unit root \\
\hline D (loredo) & $(c, t, 1)$ & -12.61083 & -4.030729 & -3.445030 & 0.0000 & no unit root \\
\hline loreint & $(c, t, 12)$ & -3.206301 & -4.036983 & -3.448021 & 0.0882 & unit root \\
\hline $\mathrm{D}$ (loreint) & $(c, t, 12)$ & -4.861461 & -4.037668 & -3.448348 & 0.0007 & no unit root \\
\hline
\end{tabular}

\begin{tabular}{cccc}
\hline \multicolumn{4}{c}{ Sequential F-statistic determined breaks: 0} \\
\hline Break Test & F-statistic & Scaled F-statistic & Critical Value \\
0 vs. 1 & 8.019301 & 8.019301 & 8.58 \\
\hline
\end{tabular}

Table 5. ADF test results ${ }^{\mathrm{a}, \mathrm{b}}$.

${ }^{a} \mathrm{D}(\bullet)$ represents the first order difference of $(\bullet),{ }^{b}$ Type $(c, t, k)$ represents (Constant, Trend, Number of lags). 
Table 6. AIC and BIC for different $\operatorname{ARMA}(p, q)^{6}$.

\begin{tabular}{cccccc}
\hline \multicolumn{5}{c}{ AIC } \\
\hline$p / q$ & 0 & 1 & 2 & 3 & 4 \\
\hline 0 & 0.751748 & -0.539915 & -1.460672 & -2.159826 & -2.459402 \\
1 & -2.781805 & -3.259236 & -3.330405 & -3.315261 & -3.308466 \\
2 & -3.266167 & -3.327296 & -3.315274 & -3.317553 & -3.309848 \\
3 & -3.308304 & -3.312432 & -3.307045 & -3.308423 & $-3.348595^{*}$ \\
4 & -3.325042 & -3.313709 & -3.302331 & -3.294682 & -3.334537 \\
\hline & & & & & \\
\hline$p / q$ & 0 & 1 & 2 & 3 & 4 \\
\hline 0 & 0.795427 & -0.474397 & -1.373314 & -2.050629 & -2.328365 \\
1 & -2.716287 & -3.171878 & $-3.221207^{*}$ & -3.184224 & -3.155590 \\
\hline 2 & -3.178810 & -3.218099 & -3.184237 & -3.164678 & -3.135133 \\
3 & -3.199107 & -3.181396 & -3.154169 & -3.133708 & -3.152041 \\
4 & -3.194005 & -3.160833 & -3.127616 & -3.098127 & -3.116143 \\
\hline
\end{tabular}

Table 7. ARMA $(1,2)$.

\begin{tabular}{ccccc}
\hline Variable & $c$ & AR (1) & MA (1) & MA (2) \\
\hline Coeff. & -0.001446 & -0.039383 & 0.872595 & 0.323792 \\
Std. Error & 0.008692 & 0.298242 & 0.303090 & 0.215987 \\
R-squared & 0.441949 & & Adj. R-squared & 0.424233 \\
Sigma & 0.001892 & & & \\
Inverted AR Roots & -0.04 & \\
\multicolumn{2}{c}{ Inverted MA Roots } & $-0.44-0.37 \mathrm{i}$ & $-0.44+0.37 \mathrm{i}$ & \\
\hline
\end{tabular}

\begin{tabular}{|c|c|c|c|c|c|c|}
\hline Autocorrelation & Partial Correlation & & $A C$ & PAC & Q-Stat & Prob \\
\hline 11 & I & & -0.005 & -0.005 & 0.0027 & \\
\hline i) & i & 2 & 0.021 & 0.021 & 0.0618 & \\
\hline i & . & 3 & 0.056 & 0.056 & 0.4810 & \\
\hline 1 & 1 & 4 & 0.066 & 0.066 & 1.0690 & 0.301 \\
\hline I) & 1 & 5 & 0.005 & 0.004 & 1.0723 & 0.585 \\
\hline I & i & 6 & 0.048 & 0.043 & 1.3959 & 0.706 \\
\hline 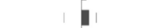 & 1 & 7 & 0.062 & 0.056 & 1.9289 & 0.749 \\
\hline I & 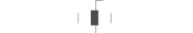 & 8 & -0.019 & -0.025 & 1.9815 & 0.852 \\
\hline 口 & 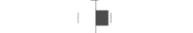 & 9 & 0.128 & 0.121 & 4.2930 & 0.637 \\
\hline - & 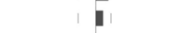 & 10 & 0.079 & 0.072 & 5.1961 & 0.636 \\
\hline 1 & 1 & 11 & 0.023 & 0.016 & 5.2719 & 0.728 \\
\hline & 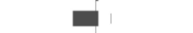 & 12 & -0.206 & -0.227 & 11.463 & 0.245 \\
\hline I & 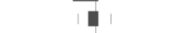 & 13 & -0.015 & -0.054 & 11.495 & 0.320 \\
\hline a & - & 14 & -0.075 & -0.088 & 12.327 & 0.340 \\
\hline I & 1 & 15 & -0.023 & -0.013 & 12.403 & 0.414 \\
\hline a & - & 16 & -0.130 & -0.131 & 14.954 & 0.310 \\
\hline I & 1 & 17 & -0.004 & 0.000 & 14.956 & 0.381 \\
\hline - & 口 & 18 & -0.141 & -0.139 & 17.987 & 0.263 \\
\hline 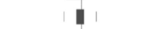 & 1 & 19 & -0.040 & -0.023 & 18.232 & 0.311 \\
\hline 1 & I & 20 & 0.007 & 0.010 & 18.239 & 0.374 \\
\hline
\end{tabular}

Figure 4. Correlogram of residuals.

${ }^{6}$ Number with asterisk shows the lowest information criterion. 


\section{VECM}

To answer the other question why import iron ore price fluctuates, a multivariate model should be considered to study the dynamic relationships between variables. Therefore, a VAR model can be considered so that the answer to the question can be analyzed from impulse response function. Also, how goodness of VECM to iron ore price can be compared to ARIMA model.

\subsection{Lag Length Selection}

To build a VAR model, the appropriate lag length needs to be selected first because too few lags will have the problem of over-parameterization, and it will cause the inefficiency of estimation. Too more lags will have the problem of parsimonious parameterization, and it will cause biased estimation. The general form of VAR is given by:

$$
Y_{t}=\Pi_{1} Y_{t-1}+\Pi_{2} Y_{t-2}+\cdots+\Pi_{i} Y_{t-i}+\epsilon_{t}, i=1,2,3,
$$

where

$$
Y_{t}=\left[\begin{array}{c}
\text { lpri } \\
\text { limport } \\
\text { loredo } \\
\text { loreint } \\
\text { bdiavg } \\
\text { dollar }
\end{array}\right], \Pi_{i}=\left[\begin{array}{cccc}
\pi_{11}^{(i)} & \pi_{12}^{(i)} & & \pi_{16}^{(i)} \\
\pi_{21}^{(i)} & \pi_{22}^{(i)} & & \pi_{26}^{(i)} \\
\vdots & \vdots & \ddots & \vdots \\
\pi_{61}^{(i)} & \pi_{62}^{(i)} & & \pi_{66}^{(i)}
\end{array}\right], \quad i=1,2,3, \epsilon_{t}=\left[\begin{array}{c}
\epsilon_{1} \\
\epsilon_{2} \\
\vdots \\
\epsilon_{6}
\end{array}\right]
$$

The lag length 5 is chosen by AIC since it has the lowest criteria of 7.891476 as shown in Table 8.

\subsection{Cointegration}

Classical time series method is based on stationary data, and there may be the problem of spurious regression if the data is non-stationary. Engle and Granger [19] demonstrate the theory of cointegration and show that even if some series are not stationary, however, their linear combination may be stationary, and this cointegration equation can be used to explain long-run equilibrium.

Table 9 shows the test results. It shows that there is at most 1 cointegration relationship and the cointegration equation is Equation (12), where standard error in parentheses:

$$
\begin{aligned}
\text { lpri }= & -\underset{(0.19353)}{0.348899 \text { limport }}+\underset{(0.20849)}{0.060433 \text { loredo }}+\underset{(0.20307)}{0.120903 \text { loreint }} \\
& -\underset{\left(0.33 \times 10^{-5}\right.}{\left(8.9 \times 10^{-6}\right)} \text { bdiavg }-\underset{(0.00632)}{0.069379 \text { bdiavg }}
\end{aligned}
$$

Since there is 1 cointegration relationship between these 6 series, VECM can by performed, and Figure 5 shows the estimation results. The first row is the estimation, the second row is standard error, and the third row is t-statistics.

\subsection{Granger Causality}

Granger Causality test shows which series has prediction ability on the other 
variable. The test results are shown in Figure 6.

The test result shows that BDI and Dollar index have Granger Causality on the price, the price has Granger Causality on international ore production and volume of import iron ore. Also, Dollar index and BDI have Granger Causality on international ore production. BDI has weak Granger Causality on domestic iron ore production, and domestic iron ore production has weak Granger Causality on international iron ore production. Both domestic and international iron ore production have Granger Causality on volume of import iron ore. These relationships are shown in Figure 7. This graph is very intuitive, and it reveals some interesting features of import iron ore price in China; the past quantity cannot help to forecast price. Instead, past price has direct ability to help to forecast the volume of import iron ore and indirect way through international mining companies' production.

\subsection{Impulse Response Function and Variance Decomposition}

In the last section, only the relationship of forecasting ability is discussed, and in this section, the magnitude and direction will be shown through both impulse response function and variance decomposition.

Table 8. VAR lag length selection ${ }^{\mathrm{a}}$.

\begin{tabular}{ccccc}
\hline Lag & LogL & LR & FPE & AIC \\
\hline 0 & -12488.908 & NA & 24.85830 & 20.24045 \\
1 & -533.0241 & 1350.942 & 0.000430 & 9.274582 \\
2 & -451.8095 & 145.4004 & 0.000208 & 8.545314 \\
3 & -401.8432 & 84.62036 & 0.000168 & 8.320051 \\
4 & -341.9132 & 95.69467 & 0.000116 & 7.934083 \\
5 & -303.2715 & $57.96245^{*}$ & $0.000115^{*}$ & $7.891476^{*}$ \\
6 & -272.1011 & 43.73922 & 0.000013 & 7.969372 \\
7 & -244.9383 & 35.48685 & 0.000161 & 8.111908 \\
8 & -219.8726 & 30.32133 & 0.000021 & 8.288269 \\
\hline
\end{tabular}

${ }^{\star} \star$ shows the lowest information criterion.

Table 9. Cointegration test.

\begin{tabular}{ccccc}
\hline & Eigenvalue & Trace Statistic & 0.05 Critical Value & Prob. \\
\hline None & 0.344011 & 114.3489 & 95.75366 & 0.0014 \\
At most 1 & 0.194429 & 60.80419 & 69.81889 & 0.2115 \\
At most 2 & 0.115270 & 33.34628 & 47.85613 & 0.5378 \\
At most 3 & 0.093858 & 17.79224 & 29.79707 & 0.5815 \\
At most 4 & 0.036780 & 5.275260 & 15.49471 & 0.7789 \\
At most 5 & 0.004056 & 0.516125 & 3.841466 & 0.4725 \\
\hline
\end{tabular}




\begin{tabular}{|c|c|c|c|c|c|c|c|c|c|c|}
\hline Error Correction: & $\mathrm{D}(\mathrm{LPRI})$ & $\mathrm{D}$ (LIMPORT) & D(LOREDO) & $\mathrm{D}($ LOREINT) & $\mathrm{D}$ (BDIAVG) & $\mathrm{D}(\mathrm{DOLLAR})$ & & & & \\
\hline \multirow[t]{3}{*}{ CointEq1 } & $=0.048475$ & 0.163873 & -0.031416 & 0.073589 & "-1531.891 & -3.137139 & & & & \\
\hline & -0.0344 & -0.07628 & -0.05859 & -0.06808 & -519.731 & -0.81422 & & & & \\
\hline & {$[-1.40927]$} & [ 2.14824$]$ & {$[-0.53623]$} & [1.08095] & {$[-2.94747]$} & {$[-3.85296]$} & & & & \\
\hline \multirow[t]{3}{*}{$\mathrm{D}(\mathrm{LPRI}(-1))$} & 0.62499 & -0.006068 & 0.259031 & -0.146629 & 1897.752 & 1.823506 & & & & \\
\hline & -0.09756 & -0.21635 & -0.16616 & -0.19308 & -1474.03 & -2.30923 & & & & \\
\hline & [ 6.40652] & {$[-0.02805]$} & [ 1.55891$]$ & {$[-0.75942]$} & [ 1.28746$]$ & [ 0.78966$]$ & & & & \\
\hline \multirow[t]{3}{*}{$\mathrm{D}(\mathrm{LPRI}(-2))$} & -0.231943 & -0.58775 & -0.112906 & 0.207762 & -1735.368 & 4.641782 & & & & \\
\hline & -0.11755 & -0.2607 & -0.20022 & -0.23266 & -1776.18 & -2.78259 & & & & \\
\hline & {$[-1.97310]$} & {$[-2.25454]$} & {$[-0.56390]$} & {$[0.89300]$} & {$[-0.97702]$} & [ 1.66815$]$ & & & & \\
\hline \multirow[t]{3}{*}{$\mathrm{D}(\mathrm{LPRI}(-3))$} & 0.079491 & -0.262643 & 0.127714 & -0.24057 & 4575.551 & -4.108264 & & & & \\
\hline & -0.11469 & -0.25434 & -0.19534 & -0.22699 & -1732.91 & -2.7148 & & & & \\
\hline & [0.69311] & {$[-1.03263]$} & [ 0.65379$]$ & {$[-1.05983]$} & [ 2.64039] & {$[-1.51329]$} & & & & \\
\hline \multirow[t]{3}{*}{$\mathrm{D}(\mathrm{LPRI}(-4))$} & 0.112874 & 0.0599 & -0.095904 & -0.348001 & -1681.503 & 4.211399 & & & & \\
\hline & -0.0948 & -0.21024 & -0.16147 & -0.18763 & -1432.42 & -2.24405 & & & & \\
\hline & [ 1.19063$]$ & {$[0.28491]$} & {$[-0.59394]$} & {$[-1.85473]$} & {$[-1.17389]$} & [ 1.87670$]$ & & & & \\
\hline \multirow[t]{3}{*}{ D(LIMPORT(-1)) } & -0.026599 & -0.754241 & -0.063696 & -0.032774 & 1736.562 & 0.93144 & & & & \\
\hline & -0.05454 & -0.12096 & -0.0929 & -0.10795 & -824.137 & -1.2911 & & & & \\
\hline & {$[-0.48766]$} & {$[-6.23539]$} & {$[-0.68563]$} & {$[-0.30360]$} & [ 2.10713$]$ & [ 0.72143$]$ & & & & \\
\hline $\mathrm{D}($ LIMPORT(-2)) & 0.035407 & -0.271275 & 0.021702 & -0.092556 & 1025.26 & 2.599725 & & & & \\
\hline & -0.06215 & -0.13782 & -0.10585 & -0.123 & -938.993 & -1.47104 & & & & \\
\hline & {$[0.56975]$} & {$[-1.96834]$} & [0.20503] & {$[-0.75251]$} & [ 1.09187$]$ & [ 1.76727$]$ & & & & \\
\hline $\mathrm{D}($ LIMPORT(-3)) & 0.045965 & -0.068721 & 0.134392 & -0.089494 & 886.826 & 0.427323 & & & & \\
\hline & -0.05506 & -0.1221 & -0.09377 & -0.10896 & -831.863 & -1.30321 & & & & \\
\hline & {$[0.83490]$} & {$[-0.56285]$} & [ 1.43317$]$ & {$[-0.82132]$} & [ 1.06607$]$ & {$[0.32790]$} & & & & \\
\hline D(LIMPORT(-4)) & -0.000595 & -0.098906 & 0.14575 & -0.071394 & 309.0533 & -1.170265 & & & & \\
\hline & -0.0419 & -0.09292 & -0.07137 & -0.08293 & -633.116 & -0.99185 & Cointegrating Eq: & CointEq1 & & \\
\hline & {$[-0.01421]$} & {$[-1.06437]$} & [2.04221] & {$[-0.86090]$} & [0.48815] & [-1.17989] & & & & \\
\hline D(LOREDO(-1)) & 0.027705 & 0.050395 & -0.556663 & 0.012229 & 447.6051 & -0.918842 & LPRI(-1) & 1.000000 & & \\
\hline & -0.06099 & -0.13526 & -0.10388 & -0.12071 & -921.526 & -1.44367 & LIMPORT(-1) & 0.348899 & & \\
\hline & [ 0.45427$]$ & [0.37259] & {$[-5.35870]$} & [0.10131] & {$[0.48572]$} & {$[-0.63646]$} & LIVIT UNT(-1) & 0.340057 & & \\
\hline D(LOREDO(-2)) & -0.036908 & -0.16193 & -0.339956 & 0.111 & 1291.652 & -3.449822 & & -0.19353 & & \\
\hline & -0.06593 & -0.14622 & -0.1123 & -0.13049 & -996.201 & -1.56066 & & [ 1.80285$]$ & & \\
\hline & {$[-0.55979]$} & {$[-1.10748]$} & {$[-3.02727]$} & [0.85064] & [1.29658] & {$[-2.21049]$} & & & & \\
\hline D(LOREDO(-3)) & -0.105509 & 0.275243 & -0.125168 & 0.066981 & 1000.737 & -2.950496 & LOREDO(-1) & -0.060433 & & \\
\hline & -0.06271 & -0.13907 & -0.10681 & -0.12411 & -947.523 & -1.4844 & & -0.20849 & & \\
\hline & {$[-1.68251]$} & [1.97916] & {$[-1.17187]$} & [0.53967] & [1.05616] & [-1.98767] & & & & \\
\hline D(LOREDO(-4)) & $\begin{array}{c}-0.052492 \\
-0.05631\end{array}$ & $\begin{array}{l}0.134751 \\
-0.12487\end{array}$ & $\begin{array}{l}0.029457 \\
-0.09591\end{array}$ & $\begin{array}{l}0.064651 \\
-0.11144\end{array}$ & $\begin{array}{c}703.7668 \\
-850.79\end{array}$ & $\begin{array}{l}0.952195 \\
-1.33286\end{array}$ & LOREINT(-1) & $\begin{array}{c}{[-0.28986]} \\
-0.120903\end{array}$ & & \\
\hline & {$[-0.93224]$} & [1.07911] & {$[0.30714]$} & {$[0.58012]$} & {$[0.82719]$} & [0.71440] & & & & \\
\hline $\mathrm{D}($ LOREINT(-1)) & 0.081158 & 0.217024 & 0.078739 & -0.674033 & -634.0557 & 0.858762 & & -0.20307 & & \\
\hline & -0.05294 & -0.11741 & -0.09017 & -0.10478 & -799.908 & -1.25314 & & {$[-0.59538]$} & & \\
\hline & [ 1.53302$]$ & [ 1.84851$]$ & [0.87323] & {$[-6.43297]$} & {$[-0.79266]$} & [0.68529] & & & & \\
\hline $\mathrm{D}($ LOREINT(-2)) & -0.006699 & 0.025842 & -0.13697 & -0.657484 & 595.2293 & -2.800044 & BDIAVG(-1) & $1.33 \mathrm{E}-05$ & & \\
\hline & -0.06111 & -0.13552 & -0.10409 & -0.12095 & -923.345 & -1.44652 & & $-8.90 \mathrm{E}-06$ & & \\
\hline & {$[-0.10962]$} & {$[0.19068]$} & {$[-1.31594]$} & {$[-5.43616]$} & [ 0.64464$]$ & {$[-1.93571]$} & & [1.48990] & & \\
\hline $\mathrm{D}($ LOREINT(-3)) & 0.000369 & 0.18931 & -0.194716 & -0.306689 & -203.4852 & -0.101433 & & & & \\
\hline & -0.06076 & -0.13475 & -0.10349 & -0.12026 & -918.098 & -1.4383 & $\operatorname{DOLLAR}(-1)$ & 0.069379 & & \\
\hline & {$[0.00607]$} & [ 1.40487$]$ & {$[-1.88142]$} & {$[-2.55023]$} & {$[-0.22164]$} & {$[-0.07052]$} & & -0.00632 & & \\
\hline $\mathrm{D}($ LOREINT(-4)) & 0.000455 & -0.268202 & -0.124702 & -0.172216 & 298.2049 & -2.222016 & & -0.00632 & & \\
\hline & -0.05613 & -0.12448 & -0.09561 & -0.1111 & -848.135 & -1.3287 & & [ 10.9813] & & \\
\hline & [0.00810] & {$[-2.15452]$} & {$[-1.30432]$} & {$[-1.55017]$} & [0.35160] & [-1.67233] & C & -14.29364 & & \\
\hline D(BDIAVG $(-1))$ & $\begin{array}{c}1.17 \mathrm{E}-05 \\
-6.30 \mathrm{E}-06\end{array}$ & $\begin{array}{c}9.80 \mathrm{E}-06 \\
-1.40 \mathrm{E}-05\end{array}$ & $\begin{array}{l}-6.79 \mathrm{E}-06 \\
-1.10 \mathrm{E}-05\end{array}$ & $\begin{array}{c}6.52 \mathrm{E}-06 \\
-1.20 \mathrm{E}-05\end{array}$ & $\begin{array}{l}0.284771 \\
-0.09533\end{array}$ & $\begin{array}{l}-0.000405 \\
-0.00015\end{array}$ & R-squared & 0.670085 & 0.582471 & 0.437804 \\
\hline & [1.84931] & {$[0.70023]$} & {$[-0.63208]$} & [ 0.52234$]$ & [2.98715] & {$[-2.70930]$} & Adi. R-squared & 0.588423 & 0.479123 & 0.298647 \\
\hline D(BDIAVG $(-2))$ & $1.34 \mathrm{E}-05$ & $9.40 \mathrm{E}-06$ & $-1.82 \mathrm{E}-05$ & $3.42 \mathrm{E}-05$ & -0.129283 & $4.52 \mathrm{E}-06$ & Adj. R-squared & 0.588423 & $0.4 / 9123$ & 0.298641 \\
\hline & $-6.50 \mathrm{E}-06$ & $-1.40 \mathrm{E}-05$ & $-1.10 \mathrm{E}-05$ & $-1.30 \mathrm{E}-05$ & -0.09773 & -0.00015 & Sum sq. resids & 0.143778 & 0.707124 & 0.417112 \\
\hline & [ 2.07274] & {$[0.65517]$} & {$[-1.65611]$} & [2.67125] & {$[-1.32283]$} & [ 0.02951$]$ & S.E. equation & 0.03773 & 0.083673 & 0.064264 \\
\hline D(BDIAVG $(-3))$ & $-2.88 \mathrm{E}-06$ & $-9.31 \mathrm{E}-06$ & $-2.03 \mathrm{E}-05$ & $1.40 \mathrm{E}-05$ & -0.054194 & $1.11 \mathrm{E}-05$ & & $0.03 / 73$ & 0.005072 & \\
\hline & $-6.80 \mathrm{E}-06$ & $-1.50 \mathrm{E}-05$ & $-1.20 \mathrm{E}-05$ & $-1.30 \mathrm{E}-05$ & -0.10259 & -0.00016 & F-statistic & 8.205569 & 5.635982 & 3.146108 \\
\hline & {$[-0.42453]$} & {$[-0.61809]$} & {$[-1.75121]$} & [ 1.04040$]$ & {$[-0.52828]$} & [0.06929] & Log likelihood & 250.5580 & 149.4066 & 182.9251 \\
\hline D(BDIAVG(-4)) & $\begin{array}{l}-2.43 E-06 \\
-6.80 E-06\end{array}$ & $\begin{array}{c}2.25 \mathrm{E}-05 \\
-1.50 \mathrm{E}-05\end{array}$ & $\begin{array}{l}-9.14 E-06 \\
-1.20 E-05\end{array}$ & $\begin{array}{c}6.85 \mathrm{E}-06 \\
-1.30 \mathrm{E}-05\end{array}$ & $\begin{array}{l}-0.334076 \\
-0.10244\end{array}$ & $\begin{array}{l}-0.00031 \\
-0.00016\end{array}$ & Akaike AIC & -3.536347 & -1.94341 & -2.471261 \\
\hline & {$[-0.35884]$} & [1.49512] & {$[-0.79132]$} & {$[0.51063]$} & {$[-3.26124]$} & {$[-1.93334]$} & Schwarz SC & -2.954073 & -1.361136 & -1.888987 \\
\hline $\mathrm{D}(\operatorname{DOLLAR}(-1))$ & -0.002735 & -0.011686 & -0.007813 & -0.000245 & -97.69575 & 0.579378 & & & & \\
\hline & -0.00397 & -0.00881 & -0.00676 & -0.00786 & -60.0095 & -0.09401 & Mean dependent & -0.002476 & 0.011293 & 0.010076 \\
\hline & {$[-0.68862]$} & {$[-1.32676]$} & {$[-1.15496]$} & {$[-0.03112]$} & {$[-1.62801]$} & [6.16284] & S.D. dependent & 0.058811 & 0.115936 & 0.076736 \\
\hline D(DOLLAR(-2)) & -0.008272 & -0.006526 & -0.008705 & -0.028931 & -5.894462 & -0.191218 & & & & \\
\hline & -0.00442 & -0.00981 & -0.00754 & -0.00876 & -66.8543 & -0.10473 & & & & \\
\hline & {$[-1.86946]$} & {$[-0.66503]$} & {$[-1.15506]$} & {$[-3.30377]$} & {$[-0.08817]$} & {$[-1.82573]$} & & & & \\
\hline $\mathrm{D}(\operatorname{DOLLAR}(-3))$ & 0.002962 & -0.016927 & -0.013366 & 0.003214 & 91.76059 & 0.250291 & & & & \\
\hline & -0.0047 & -0.01043 & -0.00801 & -0.00931 & -71.0734 & -0.11134 & & & & \\
\hline & [0.62965] & {$[-1.62269]$} & {$[-1.66824]$} & [0.34525] & [ 1.29107$]$ & [ 2.24790$]$ & & & & \\
\hline $\mathrm{D}(\mathrm{DOLLAR}(-4))$ & -0.010171 & 0.004847 & -0.005187 & 0.00078 & 89.58119 & 0.064348 & & & & \\
\hline & -0.00458 & -0.01016 & -0.0078 & -0.00907 & -69.2252 & -0.10845 & & & & \\
\hline & {$[-2.21994]$} & [0.47703] & {$[-0.66473]$} & {$[0.08603]$} & [1.29406] & [0.59335] & & & & \\
\hline C & -0.000157 & 0.01918 & 0.018989 & 0.02222 & -104.1295 & 0.058559 & & & & \\
\hline & -0.00407 & -0.00903 & -0.00693 & -0.00806 & -61.5167 & -0.09637 & & & & \\
\hline & {$[-0.03866]$} & [ 2.12431$]$ & [ 2.73837$]$ & [ 2.75754$]$ & {$[-1.69270]$} & [ 0.60763$]$ & & & & \\
\hline
\end{tabular}

Figure 5. VECM estimation result. 


\begin{tabular}{cccc}
\multicolumn{4}{c}{ Dependent variable: D(LPRISA) } \\
\hline \hline Excluded & Chi-sq & df & Prob. \\
\hline \hline D(LIMPORTSA) & 2.3870 & 4.0000 & 0.6650 \\
D(LOREDOSA) & 3.8697 & 4.0000 & 0.4239 \\
D(LOREINTSA) & 4.0709 & 4.0000 & 0.3965 \\
D(BDIAVG) & 11.9575 & 4.0000 & 0.0177 \\
D(DOLLAR) & 8.3842 & 4.0000 & 0.0785 \\
\hline \hline All & 36.8985 & 20.0000 & 0.0120
\end{tabular}

Dependent variable: D(LIMPORTSA)

\begin{tabular}{cccc}
\hline \hline Excluded & Chi-sq & df & Prob. \\
\hline \hline D(LPRISA) & 13.2438 & 4.0000 & 0.0101 \\
D(LOREDOSA) & 10.3902 & 4.0000 & 0.0343 \\
D(LOREINTSA) & 17.8458 & 4.0000 & 0.0013 \\
D(BDIAVG) & 3.2527 & 4.0000 & 0.5165 \\
D(DOLLAR) & 5.7414 & 4.0000 & 0.2193 \\
\hline \hline All & 58.6144 & 20.0000 & 0.0000
\end{tabular}

\begin{tabular}{cccc}
\multicolumn{4}{c}{ Dependent variable: D(LOREDOSA) } \\
\hline \hline Excluded & Chi-sq & df & Prob. \\
\hline \hline D(LPRISA) & 2.6681 & 4.0000 & 0.6148 \\
D(LIMPORTSA) & 5.3458 & 4.0000 & 0.2536 \\
D(LOREINTSA) & 9.4137 & 4.0000 & 0.0516 \\
D(BDIAVG) & 9.4486 & 4.0000 & 0.0508 \\
D(DOLLAR) & 7.7548 & 4.0000 & 0.1010 \\
\hline \hline All & 41.4207 & 20.0000 & 0.0033
\end{tabular}

Dependent variable: D(LOREINTSA)

\begin{tabular}{cccc}
\hline \hline Excluded & Chi-sq & df & Prob. \\
\hline \hline D(LPRISA) & 11.6560 & 4.0000 & 0.0201 \\
D(LIMPORTSA) & 1.0818 & 4.0000 & 0.8971 \\
D(LOREDOSA) & 1.0375 & 4.0000 & 0.9041 \\
D(BDIAVG) & 11.9770 & 4.0000 & 0.0175 \\
D(DOLLAR) & 12.8011 & 4.0000 & 0.0123 \\
\hline \hline All & 47.3816 & 20.0000 & 0.0005
\end{tabular}

Dependent variable: D(BDIAVG)

\begin{tabular}{cccc}
\hline \hline Excluded & Chi-sq & df & Prob. \\
\hline \hline D(LPRISA) & 8.3356 & 4.0000 & 0.0800 \\
D(LIMPORTSA) & 5.4548 & 4.0000 & 0.2437 \\
D(LOREDOSA) & 2.1210 & 4.0000 & 0.7135 \\
D(LOREINTSA) & 2.7873 & 4.0000 & 0.5940 \\
D(DOLLAR) & 8.6789 & 4.0000 & 0.0696 \\
\hline \hline All & 34.4279 & 20.0000 & 0.0234
\end{tabular}

\begin{tabular}{cccc}
\multicolumn{4}{c}{ Dependent variable: D(DOLLAR) } \\
\hline \hline Excluded & Chi-sq & df & Prob. \\
\hline \hline D(LPRISA) & 7.5561 & 4.0000 & 0.1093 \\
D(LIMPORTSA) & 7.0378 & 4.0000 & 0.1339 \\
D(LOREDOSA) & 9.6357 & 4.0000 & 0.0470 \\
D(LOREINTSA) & 11.3649 & 4.0000 & 0.0228 \\
D(BDIAVG) & 10.6754 & 4.0000 & 0.0305 \\
\hline \hline All & 40.7232 & 20.0000 & 0.0040
\end{tabular}

Figure 6. VEC Granger Causality.

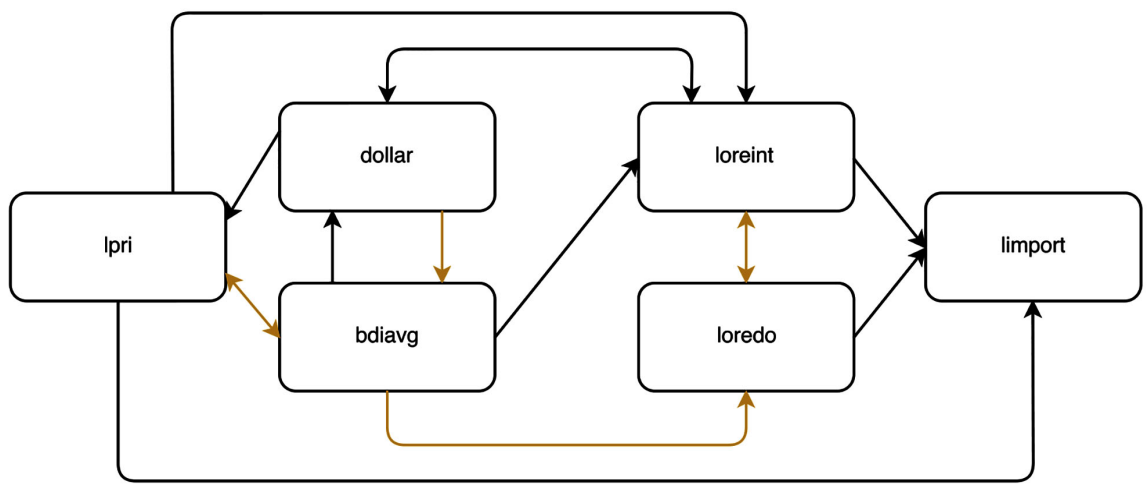

Figure 7. Granger causality graph7.

Figure 8 shows the generalized impulse response function for the response of price to the rest five series. When there is one standard deviation shock on BDI, the price has tendency to rise. This is quite intuitive; BDI is the measurement of freight, when freight is increasing while keeping FOB price constant, the iron ore price has to increase. U.S. Dollar index measures how strong U.S. Dollar is. When U.S. Dollar becomes stronger, it means that the exchange rate of U.S. Dollar goes up against to other currencies. Since bulk raw commodities are settled by U.S. Dollar, the price of commodity has to drop to maintain the same level of value as before the change, keeping other things constant. Thus, the reaction of iron ore price matches with the analysis, and it is relatively quick.

However, for the domestic and international iron ore productions and the

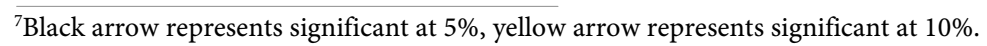


volume of import iron ore, the reactions are weakly positive and really slow; it takes four months to react. In the previous section, it shows that only past BDI and U.S. Dollar index can help to forecast iron ore price, and generally iron ore production and import cannot affect how strong U.S. Dollar is, thus, based on IRF, there is no chain effect between other variables and iron ore price. Besides, the variance decomposition of import iron ore price in Figure 9 shows that the contributions of international and domestic iron ore productions are very small after 20 periods. The possible reason that the fluctuation of iron ore price does not change much due to the shock of domestic iron ore production is that domestic mining companies do not have much more competitive power than international mining companies; the grade of domestic iron ore is too low comparing to world average. Thus, even if there is a positive shock to domestic iron ore production, the price does not fluctuate much. Also, the reason why the shock of foreign iron ore production have nearly zero response from the price may be because Chinese steel companies have less bargaining power than foreign mining companies so that how much Chinese steel companies demand and how much foreign mining companies can supply do not affect the price.
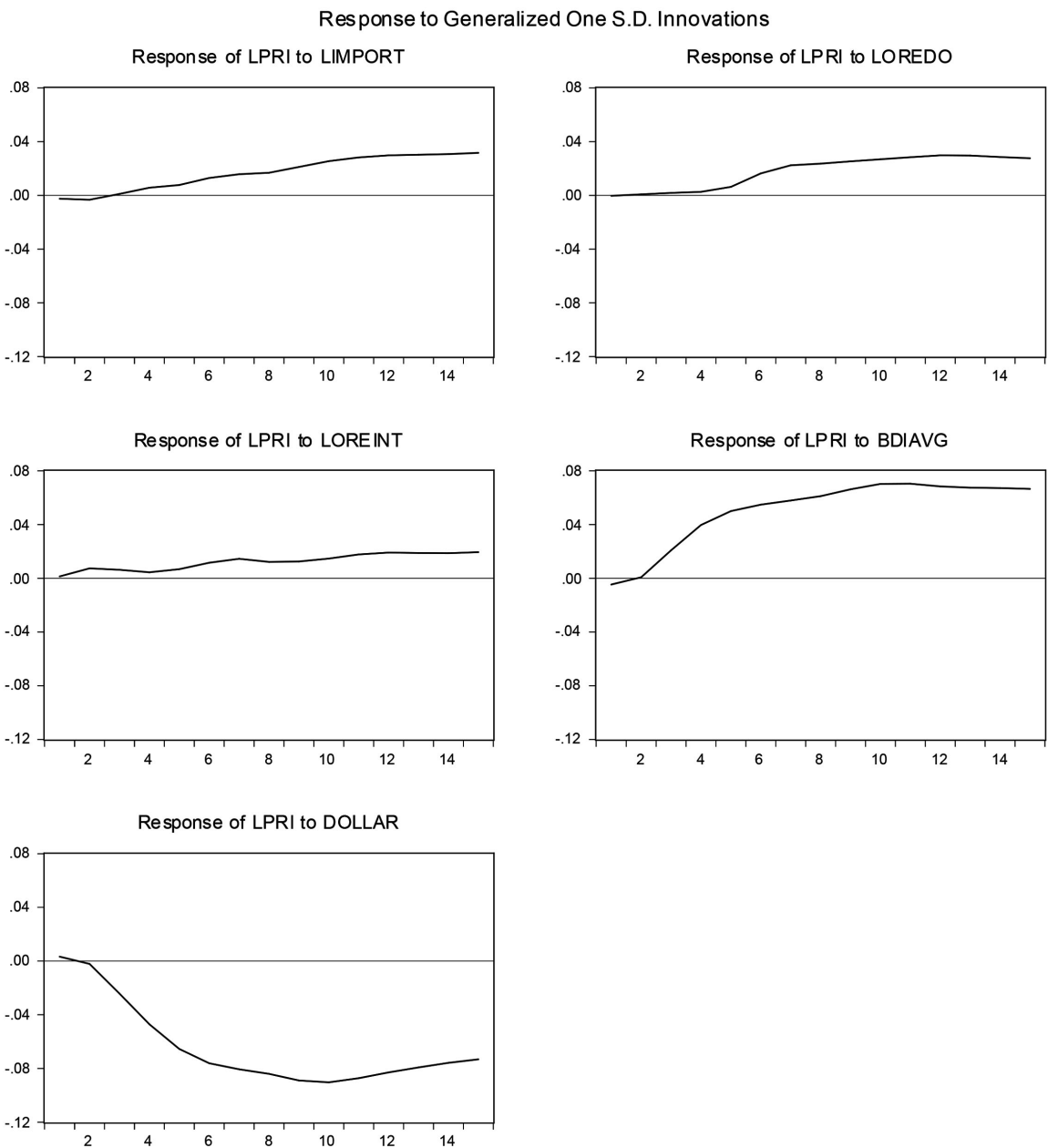

Figure 8. Impulse response function. 


\begin{tabular}{cccccccc} 
Period & S.E. & LPRI & LIMPORT & LOREDO & LOREINT & BDIAVG & DOLLAR \\
\hline \hline 1 & 0.037730 & 100 & 0.000000 & 0.000000 & 0.000000 & 0.000000 & 0.000000 \\
2 & 0.070649 & 97.52355 & 0.012896 & 0.021681 & 0.652515 & 1.275156 & 0.514201 \\
3 & 0.097635 & 85.60316 & 0.272427 & 0.013216 & 0.426084 & 8.681048 & 5.004065 \\
4 & 0.125770 & 68.32014 & 0.696910 & 0.011396 & 0.261170 & 18.30854 & 12.40185 \\
5 & 0.156461 & 54.29187 & 0.956284 & 0.033715 & 0.177595 & 24.41704 & 20.12349 \\
6 & 0.187721 & 45.13768 & 1.433697 & 0.379887 & 0.218485 & 27.03921 & 25.79104 \\
7 & 0.217925 & 39.66456 & 1.863426 & 0.853338 & 0.309280 & 28.31483 & 28.99457 \\
8 & 0.246583 & 36.23374 & 2.159140 & 1.160206 & 0.290052 & 29.29084 & 30.86602 \\
9 & 0.274757 & 33.47843 & 2.570368 & 1.330842 & 0.254450 & 30.16531 & 32.20060 \\
10 & 0.301540 & 31.34317 & 3.083340 & 1.429684 & 0.234824 & 30.99909 & 32.90989 \\
11 & 0.326030 & 30.00914 & 3.619488 & 1.514867 & 0.243691 & 31.57299 & 33.03982 \\
12 & 0.348727 & 29.48304 & 4.126885 & 1.597838 & 0.257814 & 31.79336 & 32.74107 \\
13 & 0.370339 & 29.54978 & 4.556802 & 1.646775 & 0.258720 & 31.86360 & 32.12432 \\
14 & 0.390935 & 29.93364 & 4.928523 & 1.652782 & 0.253428 & 31.88427 & 31.34735 \\
15 & 0.410485 & 30.44147 & 5.276058 & 1.631132 & 0.249794 & 31.85291 & 30.54864 \\
16 & 0.429256 & 31.05205 & 5.580278 & 1.592449 & 0.248206 & 31.75726 & 29.76976 \\
17 & 0.447491 & 31.76385 & 5.822589 & 1.548615 & 0.248477 & 31.59574 & 29.02073 \\
18 & 0.465321 & 32.50047 & 6.009153 & 1.506588 & 0.248761 & 31.41651 & 28.31851 \\
19 & 0.482847 & 33.18325 & 6.155440 & 1.464860 & 0.247166 & 31.26952 & 27.67977 \\
20 & 0.500137 & 33.77703 & 6.274340 & 1.422348 & 0.244866 & 31.15988 & 27.12154 \\
\hline \hline
\end{tabular}

Figure 9. Variance decomposition.

\section{Forecast Evaluation}

To assess the forecast ability of these two models, Figure 10 shows the fitted graph and Table 10 shows RMSE, MAE, MAPE and SMAPE for 2005M12 to 2015 M12.

The fitness of ARMA is good as expected, but it cannot be used to analyze the dynamic relationship between other variables. Also, in this paper, the multivariate model, VECM fits the historical data better than the benchmark model, ARMA.

To assess the forecast ability, these two models are re-estimated by using sample 2005M01-2015M10. Since ARMA is $(1,2)$ model, it will simply converge to the mean after two periods, therefore 1 and 2 periods ahead forecast are evaluated and shown in Table 11; both 1 and 2 period ahead forecast show that VECM can do better forecast. Figure 11 shows the forecast for 2015M11-2015M12. There is a turning point at 2015M10, however, ARMA model cannot catch it, and VECM does a great job to catch this turning point.

To see how the price will fluctuate, Figure 12 shows the comparison of ARMA and VECM for one year ahead forecast. Both models suggest that the iron ore price will continuously decrease in early 2016 and VECM suggests that the price will reach a local minimum around mid 2016. From the firm's perspective, they should progressively increase the import in the first half of 2016 and import later on. However, from Chinese government's perspective, only considering how to avoid the loss from price fluctuation is quite passive. From the previous analysis, the situation of large sellers exists in iron ore market, and China as the largest importer of iron ore seems to have weak bargaining power because its import does not fluctuate the price much in IRF. In the steel industry in China, the steel companies with production less than five million metric tons 
have more than $20 \%$ share of the total production ${ }^{8}$ in 2015 , and top ten large steel companies only have about $30 \%$ of total production. Fragmentation of Chinese steel companies seems to significantly reduce the bargaining power of Chinese steel industry. Thus, to solve the unusual fluctuation of iron ore price fundamentally, a more powerful steel association is needed. Also, due to the situation of low grade of iron ore and high cost of mining in China, Chinese steel industry heavily relies on import iron ore. Therefore, to push the technology of mining industry can reduce the cost and give domestic iron ore more competitive power thus to gain more bargaining power for Chinese steel industry.

Table 10. Model evaluation.

\begin{tabular}{ccccc}
\hline & RMSE & MAE & MAPE & SMAPE \\
\hline ARMA & 0.043530 & 0.032614 & 0.714260 & 0.713916 \\
VECM & 0.033647 & 0.026443 & 0.575656 & 0.575507 \\
\hline
\end{tabular}

Table 11.1 and 2 periods ahead forecast evaluation.

\begin{tabular}{cccccc}
\hline & Model & RMSE & MAE & MAPE & SMAPE \\
\hline 1 Period Ahead & ARMA & 0.047073 & 0.047073 & 1.165444 & 1.158692 \\
Forecast & VECM & 0.013051 & 0.013051 & 0.323126 & 0.322605 \\
2 Period Ahead & ARMA & 0.043379 & 0.043206 & 1.079110 & 1.073283 \\
Forecast & VECM & 0.024083 & 0.022255 & 0.558521 & 0.556691 \\
\hline
\end{tabular}

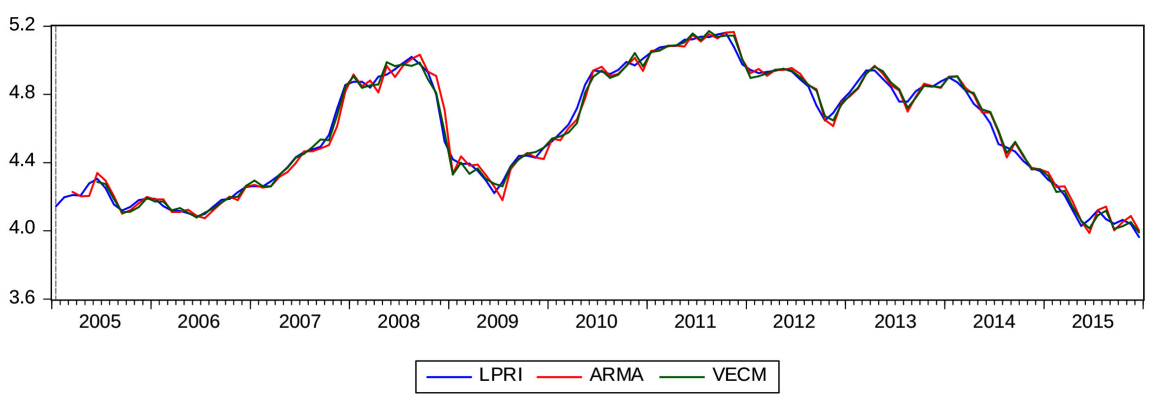

Figure 10. Fitted value graph.

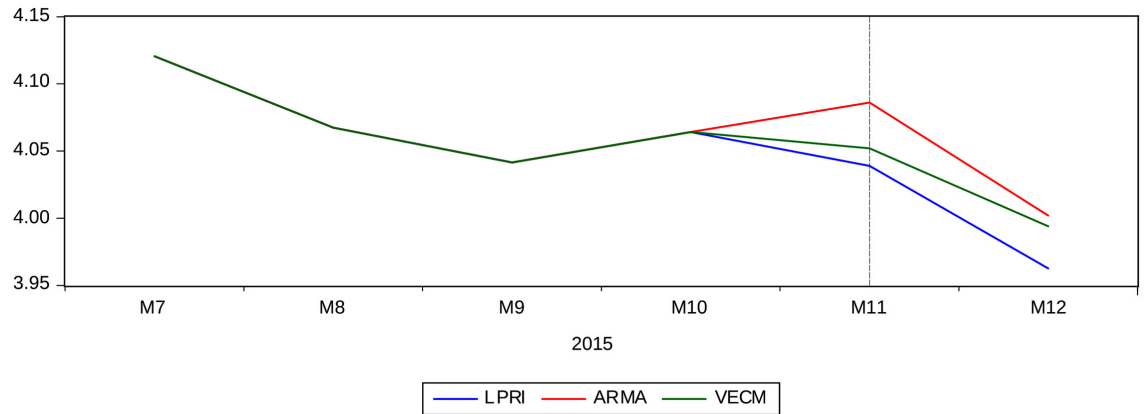

Figure 11. Forecast for 2015M11-2015M12.

${ }^{8}$ Source: Mysteel Database. 


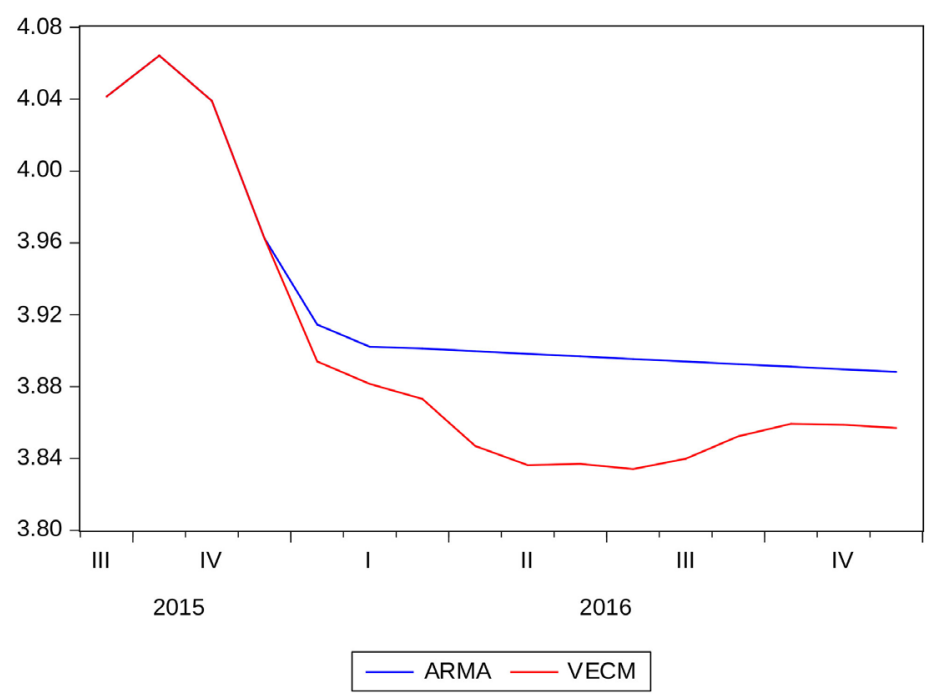

Figure 12. One year ahead forecast.

\section{Conclusions}

This paper answers two questions, how import iron ore price will fluctuate and why the price fluctuates. It analyzes the global iron ore market from both supply and demand sides and finds out the market is formed by large buyers and sellers. It also tries ARMA model and VECM to understand the fluctuation of the price, and assesses the forecast ability of these two models. In this paper, VECM outperforms the benchmark model ARMA. The results show that the import iron ore price will reach a local minimum in 2016. For Chinese steel companies, since import iron ore price may face a V-shape in 2016, they may want to increase a reasonable amount of their iron ore inventory to avoid the loss from the rebound after it hits the bottom. Also, the import iron ore price reacts very quickly to the shocks of BDI and Dollar index, steel companies should pay special attention to the tendency of these two indexes. Also, from Chinese steel companies' and the government's perspectives, they should gain more bargaining power from forming a more powerful steel association and a more concentrated industry, and push the technology innovation of mining technique. Comparing to other papers, this paper uses more recent data which is important since the market structure is changing in recent years and forecast is time sensitive. Also, it gives an assessment about the forecast ability between ARIMA model and VECM in recent iron ore market, and VECM introduced in this paper gives a very solid forecast which has a relatively low RMSE.

Due to the limited time and the lack of knowledge, there are some deficiencies in this paper. For example, there are some advanced forecast models such as ANN model and Grey model, and they may provide better forecast than ARIMA model and VECM. However, as mentioned above, the univariate model can only do the job of forecasting part, and it cannot reveal the relationship between factors. Also, there may be some potential problems with the measurement of import iron ore price in this paper, and the consequence of this is probably unde- 
termined. It is because that different levels of iron ore contain different amount of element $\mathrm{Fe}$, and the precise measurement is to calculate the total amount of element Fe imported every month. However, because of the lack of data available, this cannot be done. If there is a better measurement, the model may reveal the fluctuation of import iron ore price more precisely. Also, because of the lack of data, the foreign iron ore production is generated from only two major iron ore producer countries. It may miss some important fluctuation on the supply side. In addition, the future market of iron ore was opened in 2013. The future market may play a significant role in the fluctuation of import iron ore price since iron ore has its financial characteristics. Therefore, in the future, when there is more data available, the measurement of price and supply side can be improved, and the performance of the future market of iron ore can be added into the model when the future market has more influence on the iron ore market. Also, when time permits, models like ANN or Grey model can be discussed in details.

\section{Conflicts of Interest}

The author declares no conflicts of interest regarding the publication of this paper.

\section{References}

[1] Zhu, Z.R. (2012) Identifying Supply and Demand Elasticities of Iron Ore. PhD Thesis, Duke University, Durham.

[2] Jones, A. (1986) Prospects for an Iron Ore Cartel. Resources Policy, 12, 103-115. https://doi.org/10.1016/0301-4207(86)90015-2

[3] Crompton, P. and Lesourd, J.-B. (2004) Economies of Scale in the Global Iron-Making Industry. Economics Program, School of Economics and Commerce, University of Western Australia, Perth.

[4] Pustov, A., Malanichev, A. and Khobotilov, I. (2013) Long-Term Iron Ore Price Modeling: Marginal Costs vs. Incentive Price. Resources Policy, 38, 558-567. https://doi.org/10.1016/j.resourpol.2013.09.003

[5] Cummins, J.D. and Griepentrog, G.L. (1985) Forecasting Automobile Insurance paid Claim Costs Using Econometric and ARIMA Models. International Journal of Forecasting, 1, 203-215. https://doi.org/10.1016/0169-2070(85)90003-2

[6] Zhang, G.P. (2003) Time Series Forecasting Using a Hybrid ARIMA and Neural Network Model. Neurocomputing, 50, 159-175. https://doi.org/10.1016/S0925-2312(01)00702-0

[7] Eswaran, C. and Logeswaran, R. (2010) A Comparison of ARIMA, Neural Network and Linear Regression Models for the Prediction of Infant Mortality Rate. 4th Asia International Conference on Mathematical/Analytical Modelling and Computer Simulation (AMS), Bornea, 26-28 May 2010, 34-39.

[8] Khalifa, A.A.A., Miao, H. and Ramchander, S. (2011) Return Distributions and Volatility Forecasting in Metal Futures Markets: Evidence from Gold, Silver, and Copper. Journal of Futures Markets, 31, 55-80. https://doi.org/10.1002/fut.20459

[9] Tcha, M.J. and Wright, D. (1999) Determinants of China's Import Demand for Australia's Iron Ore. Resources Policy, 25, 143-149.

https://doi.org/10.1016/S0301-4207(99)00015-X 
[10] Moghaddam, M.R., Manjezi, M., Hossein, A. and Kakha, H. (2014) Prediction of Monthly Price of Iron Ore by Using Artificial Neural Network. Indian Journal of Scientific Research, 7, 1200-1204.

[11] Deng, J.L. (1989) Introduction to Grey System Theory. The Journal of Grey System, 1, 1-24.

[12] Ma, W.M., Zhu, X.X. and Wang, M.M. (2013) Forecasting Iron Ore Import and Consumption of China Using Grey Model Optimized by Particle Swarm Optimization Algorithm. Resources Policy, 38, 613-620. https://doi.org/10.1016/j.resourpol.2013.09.007

[13] Haque, M.A., Topal, E. and Lilford, E. (2015) Iron Ore Prices and the Value of the Australian Dollar. Mining Technology, 124, 107-120. https://doi.org/10.1179/1743286315Y.0000000008

[14] Wårell, L. (2014) The Effect of a Change in Pricing Regime on Iron Ore Prices. Resources Policy, 41, 16-22. https://doi.org/10.1016/j.resourpol.2014.02.002

[15] He, W.D. and Yu, Y. (2012) A Game Theory Analysis in Trade Security of Iron Ore. International Proceedings of Economics Development and Research (IPEDR), 49, 81-86.

[16] Bai, J.S. (1997) Estimating Multiple Breaks One at a Time. Econometric Theory, 13, 315-352. https://doi.org/10.1017/S0266466600005831

[17] Bai, J.S. and Perron, P. (2003) Computation and Analysis of Multiple Structural Change Models. Journal of Applied Econometrics, 18, 1-22. https://doi.org/10.1002/jae.659

[18] Bai, J.S. and Perron, P. (1998) Estimating and Testing Linear Models with Multiple Structural Changes. Econometrica, 66, 47-78. https://doi.org/10.2307/2998540

[19] Engle, R.F. and Granger, C.W.J. (1987) Co-Integration and Error Correction: Representation, Estimation, and Testing. Econometrica: Journal of the Econometric Society, 55, 251-276. 